\title{
Politics and Faith (1)
}

\section{Política e fé (1)}

\author{
Guy Hammond **
}

Politics and Faith: Reinhold Niebuhr and Paul Tillich at Union Seminary in New York, by Ronald H. Stone (Macon, Georgia: Mercer University Press, 2012), 486p.

Política e fé: Reinhold Niebuhr e Paul Tillich no Union Seminary em New York, por Ronald H. Stone (Macon, Georgia: Mercer University Press, 2012), 486 p.

Everyone interested in the lives and careers of the two greatest American philosopher theologians of the 20th century-Reinhold Niebuhr and Paul Tillich-will rejoice at the publication of Ronald Stone's magnum opus, Politics and Faith: Reinhold Niebuhr and Paul Tillich at Union Seminary. Stone's personal connections with the two great figures, and his previous publications dealing with their lives and thought, place him in an unrivaled position to review their activities and interactions in the crucial period of 1933 to 1955, when they were col- leagues at Union Seminary. This work is a monumental effort that sheds new light on their perspectives, and indeed provides new insights into that whole period of American history.

Central to both men's experience in this time period, especially given Stone's focus on issues of politics and faith, was the inescapable

* Bulletin of the North American Paul Tillich Society. Volume XXXIX, Number 2, Spring 2013, p. 3-5.

** Member of the North American Paul Tillich Society. Author of Man in estrangement: a comparison of the thought of Paul Tillich and Erich Fromm Published by Vanderbilt University Press, Nashville (1965) and Conscience and Its Recovery: From the Frankfurt School to Feminism (Studies in Religion and Culture), Published by University of Virginia Press (1993). Deceased in January 2018. 
impact of world wars, in prospect, reality, or retrospect. In his early pages Stone gives a prefatory glimpse of the two on different sides of the conflict in World War One, both falling into, and discovering the limitations of, sanctified nationalism. Then, after Tillich had fled Germany with the advent of Nazism, they found themselves together at Union Seminary, con- fronting the renewal of European conflict, and the need to find meaning in the midst of another world-wide cataclysm.

To what extent did they come to share a common perspective? Stone weighs the evidence judiciously, acknowledging differences where they existed, but in the end portraying a remarkable overall agreement on issues of greatest moment. Despite of Niebuhr and Tillich in the early thirties, noting that their most socialist books, Niebuhr's Moral Man and Immoral Society and Tillich's The Socialist Decision, appeared at the same time (1932-1933). Niebuhr subsequently abandoned socialism and tensions at various points, this agreement provided a firm basis for a broadly neo-liberal (not neo- orthodox) theology in the post-war period.

No review can do justice to Stone's richly de- tailed accounts of how Niebuhr and Tillich-jointly or separately-responded to the countless issues that arose during the period in question. A few selected topics may be taken as representative.

Stone provides an interesting assessment of the socialism embraced Roosevelt's New Deal, while Tillich continued to identify himself with his version of religious socialism, but came to understand that it was not "politically relevant" (74) in the United States; both could be said to have adopted a pragmatic, rather than a doctrinaire approach to economic and political issues. Stone shows how both sought to move beyond Marxism while preserving the benefits of a Marxist critique of society in Christian social ethics (85).

Although it was Tillich who used the phrase,

"On the Boundary" to describe his own circumstances in life and thought, Stone finds it useful to describe ways in which both Tillich and Niebuhr saw themselves in "boundary" situations. For example, both stood on the borderline between theology and philosophy. Tillich was more overt in acknowledging his vocation as at once philosopher and theologian. Niebuhr was more critical of philosophy, and "turned more quickly to the 
biblical symbols" (79); but American pragmatism became more and more crucial to his perspective, not always overtly. Though German idealism was alien to Niebuhr, and pragmatism was deficient as an overarching philosophy in Tillich's view, both made use of existential- ism (363).

Before and during World War II, Stone sees Niebuhr and Tillich arriving at a remarkable unanimity of political perspectives. Niebuhr had abandoned his earlier pacifist leanings, and both were highly critical of Christian liberalism's utopian idealism. Together they constructed a "Christian real- ism" that was relevant to the times. (Regrettably, Stone does not give extended treatment of Tillich on estrangement to parallel his masterful summation of Niebuhr on sin and salvation (120-132).) One of Stone's narrations captures the flavor of the debates: Both Niebuhr and Tillich were asked, in 1943, to contribute to the work of the Commission on a Just and Durable Peace of the Federal Council of Churches. The Commission was chaired by John Foster Dulles, who was "a hardened proponent of the capitalist spirit." Niebuhr must have smiled, says Stone, at the thought of Tillich writing for the Commission; Tillich's perspective reflected his "sense of a world in revolt against the capitalist spirit" (154). Antagonism between the two and Dulles - who later became Secretary of State-only deepened in following years. Ultimately both sought to defend a middle way between "totalitarian absolutism" and "liberal individualism" (185). Though they were close politically, Niebuhr "offered a more thorough defense of democracy," while Tillich maintained that Western political forms were not necessarily transferable in totality to other parts of the world (185-186).

In the post-war years, Stone discerns a certain degree of divergence between Niebuhr and Tillich. While Niebuhr continued to address issues of national and international politics, Tillich-with a few exceptions - pulled back from active political involvement. His one major scholarly publication of the time that dealt with historical and political is- sues, The Protestant Era (1948), pointed back to themes he had developed prior to World War II (263). Secondly, in other important works of the period-in the sermons of The Shaking of the Foundations (1948) as well as in the Systematic Theology, vol. I (1951) - Tillich's doctrine of the Spirit became "very prominent," 
while, says Stone, this theme was "almost absent in Niebuhr's preaching and in his formal theological writing" (266). And lastly, of course, Tillich turned his primary attention toward the writing of his systematic theology, rather than being preoccupied with the Cold War and other is- sues in the realm of social ethics.

These divergences were real, but Stone is convinced that they were relatively superficial, counter- acted by continuing underlying common commitments. In part to demonstrate this, Stone engages in a "social analysis of Tillich's Systematic Theology" in a chapter entitled "Tillich's Later Social Ethics" (289ff). Noting Tillich's statement (in Volume I) that "it is not the task of the systematic theologian to set forth a political program or a social philosophy," and that the system does not include a specific section on social ethics (290-291), Stone observes that the whole of Tillich's theology is written in dialogue with contemporary thinkers, not least with political philosophers of the time. For example, in the epistemology of Part One, Stone mentions Tillich's important citation of political philosopher Max Horkheimer's analysis of "technical reason" (292). Though Part Two of Volume One (Tillich's doctrine of God) is "relatively empty of social analysis" (293), it remains clear that Tillich's ontological con- cept of God is designed to provide a firm basis for a social ethics (293). Stone grants that Systematic Theology, Vol. II, is "except for a few referencesapolitical" (294). (Tillich did not engage in the more recently prominent debates about Jesus' relation to issues of politics and empire). Regarding Volume III, the dominance of the Spirit (along with mysticism and ontology) evoked Niebuhrian criticism (tradition has it that Niebuhr said regarding Volume III: "he's even more heretical than I thought he was" (295)). On the other hand, however, the concluding section of Volume III "contributed to the revival of the symbol of the Kingdom of God as a central symbol for social theology," a tendency not matched in Niebuhr, but seemingly a compatible supplement to his work; Niebuhr used the Kingdom of God symbol primarily as a "principle of critique" of other utopias (422).

In summary, both Niebuhr and Tillich eschewed simplistic solutions to the problem of relating politics and faith. Stone writes: "Some interpretations of Christian faith are relatively apolitical, 
others almost totally political. These two lived and taught a vigorous commitment to politics for the common good or justice, but with a Christian reservation about politics, and Christian resources for life beyond politics" (416-417). They both generally refrained from applying Christian doctrine directly to political issues. "For both Niebuhr and Tillich it is a more complicated process moving through social ethical judgments, political philosophy and then policy and party strategies" (419).

Stone sums up his depiction of the two great thinkers' complementary relationship in terms of love, power, and justice: "Niebuhr wrestled for years with the dialectic of love and justice. At last, he talked about it as Christian love inspiring the struggle for justice utilizing power. Tillich provided a philosophy of love, justice, and power for Niebuhr's more pragmatic synthesis. Niebuhr's dialectic gives the push for the never-ending struggle for justice, and Tillich provides a rationale for their necessary relationship with each other and with power" (444).

Stone's Politics and Faith will stand alongside Richard Fox's Reinhold Niebuhr: A Biography and Wilhelm and Marion Pauck's Paul Tillich: His Life and Thought as an indispensable source for knowledge regarding the lives and thought of these two towering figures in $20^{\text {th }}$ century philosophical theology. 